\title{
Feeding preferences of ostriches towards the inclusion of full-fat canola seed in grower diets
}

\author{
T.S. Brand ${ }^{1,2 \#}$, G.J. Niemann ${ }^{2}$, A. Muller ${ }^{2}$ \& L.C. Hoffman ${ }^{2}$ \\ ${ }^{1}$ Directorate for Animal Sciences, Western Cape Department of Agriculture, Private Bag X1, \\ Elsenburg, 7607, South Africa \\ ${ }^{2}$ Department of Animal Sciences, University of Stellenbosch, Private Bag X1, Matieland, 7602, South Africa
}

(Received 6 December 2017; Accepted 16 July 2018; First published online 20 November)

\author{
Copyright resides with the authors in terms of the Creative Commons Attribution 4.0 South African License. See: \\ http://creativecommons.org/licenses/by/4.0/za \\ Condition of use: The user may copy, distribute, transmit and adapt the work, but must recognize the authors and the South African \\ Journal of Animal Science.
}

\begin{abstract}
The largest expense of an intensive ostrich production unit is feed cost (ca.75\%). Protein makes up a great portion of feed for monogastric animals and this expense can be lowered by utilizing locally produced feedstuffs such as full-fat canola, although it is not clear whether ostriches will readily consume full-fat canola because of its anti-nutritional and other known factors. To evaluate the feeding preference of ostriches towards full-fat canola, 60 South African Black ostriches $(82.2 \pm 1.06 \mathrm{~kg}$ in live weight) were placed in 10 camps of six birds per camp. Each camp had five identical feed troughs containing diets in which full-fat canola seed (FFCS) incrementally $(0,25,50,75$ and $100 \%$ of protein source) replaced the soybean oilcake meal $(9.8 \%$ of the total diet composition in control diet was soybean oilcake meal and full-fat canola was included up to $27.5 \%$ of the total diet) as protein source. Dry matter intake (DMI) was measured daily and feed colour characteristics were measured, based on $\mathrm{L}^{*}, \mathrm{a}^{*}$ and $\mathrm{b}^{*}$ colour attributes. Only the $25 \% \mathrm{FFCS}$ showed a higher DMI $(817.38 \pm 81.98 \mathrm{~g} / \mathrm{bird} /$ day $)$ and percentage DMI $(\sim 29.53 \%)$ than the other diets, with an average DMI of $488.8 \mathrm{~g} / \mathrm{bird} /$ day) and percentage DMI of $17.62 \%$. Although the $0 \% \mathrm{FFCS}, 50 \% \mathrm{FFCS}$ and $75 \%$ FFCS had a lighter colour than the $25 \%$ FFCS and $100 \%$ FFCS and the $b^{*}$ colour parameter for $100 \%$ FFCS was lower than the rest, it is believed that these differences had no effect on DMI. Based on the results of this study, diets with up to $27.5 \%$ full-fat canola seeds had no detrimental effect on feed intake of finishing ostriches. Birds prefer diets with a combination of $6.9 \%$ full-fat canola seed and $7.4 \%$ soybean oilcake meal.
\end{abstract}

Keywords: Anti-nutrients, dry matter intake, feed colour, feed palatability, glucosinolates, ostrich

\# Corresponding author: tersb@elsenburg.com

\section{Introduction}

Ostrich farming is a relatively new practice compared with those of cattle, sheep and other livestock. Smit (1964) noted that ostrich farming started only between 1857 and 1864, although in England and Wales in 1086 farmers were already rearing livestock with numbers of over 100 cattle and 9000 sheep on one farm alone (Thirsk, 1989). Owing to the relatively young age of the ostrich industry, there is still room for improvement in production practices.

Ostriches are multi-purpose animals that produce feathers, skins (leather) and meat. Initially ostriches were reared mainly for their feathers, which were incorporated in the fashion industry (Osterhoff, 1979). Intensive ostrich farming started only in the 1960s, after which the industry began to change, with leather becoming the predominant commodity in 1975. The 1980s then saw an increase in the popularity of ostrich meat (Van Zyl, 2001).

Food product consumption of animal origin has increased rapidly. It is predicted that per capita demand for these products will increase even more in developing countries (Bradford, 1999). With population growth, and an increase in living standards and urbanization, the demand for higher quality protein has grown. China and other Asian countries have already shown an increase in demand for animal products (Bradford, 1999; Cao \& Li, 2013). Between 1997 and 1999 worldwide, total meat production was 218 million tons, with the prediction that it would rise to 376 million tons in 2030 (Gardner, 2013). To meet the fastgrowing demand for animal food products, production systems on the farms need to be optimized and input 
costs reduced. Ostrich meat is considered healthier than other meats owing to its low fat content and favourite composition of fatty acids (Harris et al., 1994; Sales \& Hayes, 1996; Girolami et al., 2003) and could contribute to supplying animal protein to local populations and international markets.

The largest expense of an intensive ostrich production system is feed (Aganga et al., 2003; Brand \& Jordaan, 2004), which can account for about $75 \%$ of total input costs (Brand \& Jordaan, 2004). The profitability of an intensive ostrich production unit could be improved by lowering the feeding costs (Brand \& Jordaan, 2004; Jordaan et al., 2008). Several factors other than feed cost influence profitability, which the farmer cannot control. Thus it is important to optimize factors such as nutrition, which can be controlled by the producer to some degree (Carstens, 2013). Brand \& Jordaan (2004) stated that feed costs can be reduced by using well-formulated least-cost diets and incorporating locally produced feedstuffs. Engelbrecht (2016) reported on similar feed cost reduction solutions, emphasizing that as long as these solutions are not detrimental to end product quality they can be utilized to reduce feed cost.

Protein is essential for growth and optimal production of animals (Abudabos \& Aljumaah, 2012). According to Brand \& Gous (2006), protein can constitute up to $22.8 \%$ of a diet, depending on the feeding phase that the ostriches are in. With global population growth, protein is becoming scarcer, more expensive, and less available to be utilized as animal feed, which necessitates research into finding alternative protein sources (Brand et al., 2000a; Brand et al., 2004; Sridhar \& Bhat, 2007). Canola is produced locally in the province of Western Cape, South Africa, and could be utilized as a protein source in animal rations, replacing soybean oilcake meal (Brand et al., 2007). Brand et al. (2000a) evaluated FFCS as a potential protein and energy source for ostriches and found that it contained $192 \mathrm{~g}$ crude protein (CP)/kg feed and $11.2 \mathrm{glysine} / \mathrm{kg}$ feed. Canola has long been used in other animal feeds such as poultry (Ajuyah et al., 1991; Lee et al., 1991), pigs (Busboom et al., 1991), and ruminants (Mir et al., 1984). However, information is not available about the suitability of canola in ostrich diets. The use of rapeseed in animal feed is limited owing to high levels of glucosinolates and erucic acid (Bell, 1993). However, the development of double zero canola cultivars (a rapeseed cultivar containing lower levels of these anti-nutrients) has made it possible to include higher levels in diets for animals (Dale, 1996).

The aim of this study was therefore to determine the optimal FFCS inclusion level for grower ostrich in a balanced diet based on animal preference, without reducing DMI.

\section{Materials and Method}

The trial was conducted in May 2016 at Oudtshoorn Research Farm $\left(22^{\circ} 25^{\prime} \mathrm{E}, 33^{\circ} 63^{\prime}\right.$ S, altitude 307 $\mathrm{m}$ ) in the Klein Karoo region of South Africa. Ethical clearance for this study was obtained from the Elsenburg Ethical Committee (R14/108). The trial ran for 10 days, with the first part being conducted over five days, with a seven-day rest interval, followed by another five-day trial period. In this trial, 60 ostriches at 233 days old, weighing $82.2 \pm 1.06 \mathrm{~kg}$, were divided into 10 camps $(32 \mathrm{~m} \times 30 \mathrm{~m})$, which contained six animals per camp in a randomised block design.

Each camp had five feeding troughs $(46 \mathrm{~cm} \times 23 \mathrm{~cm} \times 20 \mathrm{~cm}$ ) in a fixed position, which contained a different diet based on the FFCS inclusion level to evaluate whether there were a preference for certain diets. Feeding trough allocation was interchanged in the camps so that only two camps had the same order. Throughout the trial, feed and water troughs $(29 \mathrm{~cm} \times 20 \mathrm{~cm} \times 15 \mathrm{~cm})$ were monitored three times daily to ensure animals had feed and water ad libitum. The feed in all troughs was mixed twice a day by hand to stimulate feed intake. Daily feed supply was recorded and refusals were weighed back the next day at the same time for the whole trial. Refusals were subtracted from the feed supplied to determine daily feed intake for each diet.

Mixit2+ software (Agricultural Software Consultants Inc., San Diego, USA) was used to formulate the five iso-nutritional diets (in terms of energy and amino acid contents) with various FFCS inclusion levels. The optimization model to predict nutritional requirements of ostriches that was developed by Gous \& Brand (2008) aided in formulating balanced diets. The control diet contained only soybean oilcake meal $(9.8 \%$ of the total diet composition) as the main protein source. The four treatment diets were formulated so that FFCS replaced the soybean oilcake meal in the diets incrementally $(6.9,13.8,20.6$ and 27.5\% FFCS inclusion) (Table 1). Balanced diets were formulated and adjusted primarily for metabolizable energy (ME) by including oat hulls to compensate for the higher fat content of FFCS because ostrich intake is determined by the energy contents of the feed. Other requirements were adjusted to nutrient specifications. The diet formulations and nutrient compositions are presented in Table 2.

The control diet with no FFCS is referred to henceforth as 0\%FFCS. The maximum FFCS inclusion (27.5\%) diet is referred to as $100 \%$ FFCS, because FFCS replaced all of the soybean oilcake meal in the diet. The remaining three FFCS inclusion levels are expressed as percentages of 27.5 (100\%FFCS), thus as 25\%FFCS, 50\%FFCS and 75\%FFCS (Table 1). 
Table 1 Percentage full-fat canola seed and soybean oilcake meal inclusion in treatment diets

\begin{tabular}{lccccc}
\hline \multirow{2}{*}{ Protein source (\%) } & \multicolumn{4}{c}{ Diets expressed as percentage of full-fat canola seed replacing soybean oilcake meal } \\
\cline { 2 - 5 } & 0\% FFCS & 25\% FFCS & 50\% FFCS & 75\% FFCS & 100\% FFCS \\
\hline Full-fat canola seed & 0.0 & 6.9 & 13.8 & 20.6 & 27.5 \\
Soybean oilcake meal & 9.8 & 7.4 & 4.9 & 2.5 & 0.0 \\
\hline
\end{tabular}

FFCS: full-fat canola seed

Feed was milled and pelleted $(8 \mathrm{~mm} \varnothing)$ and approximately $1.5 \mathrm{~kg}$ of feed was sampled for each oneton batch of every diet when pelleted. Samples were ground with the Retsch TM ZM200 sample mill (Haan, Germany) using a $1.5 \mathrm{~mm}$ screen for further chemical analyses. Ground samples were analysed to verify that the diets contained the formulated nutrient levels.

These fractions and components were determined, namely dry matter (DM), crude fibre (CF), acid detergent fibre (ADF), neutral detergent fibre (NDF), ether extract (EE), ash, crude protein (CP), metabolizable energy (ME), calcium (Ca), phosphorus $(P)$ and amino acids. Analyses were based on the methods of the Association of Official Analytical Chemists (AOAC, 2012) and are presented in Table 2.

Dry matter determination included drying a $2 \mathrm{~g}$ sample for 24 hours at $100{ }^{\circ} \mathrm{C}$ (AOAC, 2012) (method 934.01). Crude fibre (Goering \& Van Soest, 1970), ADF and NDF (Van Soest et al., 1991) were obtained with the ANKOM A200 fibre analyzer (ANKOM Technology Corporation, New York, USA). Ether extract was determined with a Tecator Soxtec system HT 1043 (Tectator, Höganas, Sweden) and the extraction fluid diethyl-ether (AOAC, 2012) (AOAC method 2003.06). Ash was ascertained with the Labcon Muffle furnace RM7 (Labcon, Johannesburg, South Africa) (AOAC method 942.05). Crude protein was calculated from the nitrogen content determined with a LECO TruMac $N$ nitrogen determinator, version 1.3X (LECO Corporation, Michigan, USA) using the factor N x 6.25 (AOAC, 2012) (AOAC method 990.03). Amino acid content (Table 2) was established using a method developed by the Central Analytical Facilities (CAF) at Stellenbosch University. This includes hydrolysis of milled feed samples in hydrochloric acid and Waters Acquity ultra performance liquid chromatography (UPLC) with UV or fluorescence detection after derivatization with 6-aminoquinolyl-N-hydroxysuccinimidyl carbamate (AQC) (Taylor, 2017).

Samples were analysed for $\mathrm{Ca}$ and $\mathrm{P}$ with the dry ashing method of Agri Laboratory Association of South Africa (ALASA, 1998) (method 6.1.1). The Thermo Electron iCAP 6000 Series inductively coupled plasma (ICP) spectrophotometer (Thermo Electron Corporation, Milan, Italy) with a vertical quartz torch fitted with a Cetac ASX-520 auto sampler was used to measure $\mathrm{Ca}$ and $\mathrm{P}$ concentrations (Table 2). Merck Titrisol standards (1000 ppm) (Merck, Darmstadt, Germany) and iTEVA Analyst software were used to calculate the $\mathrm{Ca}$ and $\mathrm{P}$ concentrations.

Glucosinolate concentrations in the FFCS were determined based on an adapted method of liquid chromatography-mass spectrometry (LC-MS) described by Sasaki et al. (2012). The Waters Synapt G2 system (ESI probe, ESI negative, cone voltage $15 \mathrm{~V}$ with a Waters $\mathrm{BEH} \mathrm{C} 18$ column at $55^{\circ} \mathrm{C}(17 \mu \mathrm{m}, 2.1 \mathrm{x}$ $100 \mathrm{~mm}$ )) was used for the analysis (Waters Corporation, Milford, USA) with $0.1 \% \mathrm{NH}_{4} \mathrm{OH}$ and acetonitrile as solvents. After the glucosinolate content of the FFCS had been determined, it was multiplied by the percentage FFCS in each diet to obtain the concentration of glucosinolates (Table 3).

Feed colour was measured to establish whether the five diets differed in colour, which might have an effect on diet preference. A colour-guide $45^{\circ} / 0^{\circ}$ colorimeter $(20 \mathrm{~mm}$ aperture and D65/10 illuminant/observer ratio) (Catalogue number 6805, BYK-Gradner $\mathrm{GmbH}$, Geretsried, Germany) was used to measure the surface colour of unground (as-fed) feed samples of each diet, according to the three CIE LabSystem colour attributes of L* (lightness), $a^{*}$ (green-red) and b* (blue-yellow). Calibrations were carried out with the standards provided (BYK-Gradner). For the measurements, samples were spread evenly in a deep circular flat-bottomed container before five readings were taken on the surface in various locations of each diet.

Data were analysed statistically to determine whether there were significant differences at the $P \leq 0.05$ level among diets. Analysis of variance (ANOVA) was performed on the CIE Lab-System colour attributes to establish whether there were significant colour differences among the diets by using Fisher's least significant difference (LSD) $t$ test. Randomised block ANOVA with the GLM procedure of SAS Enterprise Guide (version 9.4) (SAS Institute Inc., Cary, NC, USA) aided in verifying whether there were significant differences for DMl/bird/day and percentage dry matter intake (\%DMI)/bird/day between diets. Percentage DMI for a diet 
was calculated as DMI/day of a specific diet in a certain camp divided by total DMI/day of all the diets in that camp multiplied by 100 . Analyses were performed on average intake/bird/camp/day for each of the diets over the 10 trial days. Fisher's LSD was used to determine which diets differed.

Table 2 Ingredients and chemical composition of diets containing incremental levels of full-fat canola seed in a preference study (as fed basis)

\begin{tabular}{|c|c|c|c|c|c|}
\hline \multirow{2}{*}{ Ingredients kg/ton } & \multicolumn{5}{|c|}{$\begin{array}{l}\text { Diets expressed as the percentage full-fat canola seed replacing soybean } \\
\text { oilcake meal }\end{array}$} \\
\hline & $0 \%$ FFCS & $25 \%$ FFCS & $50 \%$ FFCS & $75 \%$ FFCS & $100 \%$ FFCS \\
\hline Full-fat canola & 0.00 & 68.8 & 137.6 & 206.4 & 275.1 \\
\hline Corn (Yellow grain) & 492.2 & 419.2 & 346.2 & 273.2 & 200.2 \\
\hline Lucerne meal, 17\% CP & 246.1 & 227.1 & 208.1 & 189.1 & 170.2 \\
\hline Oats hulls & 18.4 & 66.1 & 113.8 & 161.5 & 209.2 \\
\hline Soybean oilcake meal, 44\% CP & 98.4 & 73.8 & 49.2 & 24.6 & 0.00 \\
\hline Molasses meal & 80.0 & 80.0 & 80.0 & 80.0 & 80.0 \\
\hline Limestone, ground & 26.30 & 26.86 & 27.42 & 27.98 & 28.54 \\
\hline Kynofos 21/ $\mathrm{MCP}^{1}$ & 22.44 & 21.77 & 21.10 & 20.42 & 19.75 \\
\hline Common salt $/ \mathrm{NaCl}^{2}$ & 9.84 & 9.88 & 9.93 & 9.97 & 10.01 \\
\hline Vitamin \& mineral premix* & 5.00 & 5.00 & 5.00 & 5.00 & 5.00 \\
\hline Bentonite & 20.00 & 20.00 & 20.00 & 20.00 & 20.00 \\
\hline Synthetic lysine (L-lysine 95\%) & 1.34 & 1.49 & 1.65 & 1.80 & 1.95 \\
\hline \multicolumn{6}{|l|}{ Nutrients } \\
\hline $\mathrm{ME}^{3} \mathrm{MJ} / \mathrm{kg}$ feed & 11.5 & 11.5 & 11.5 & 11.5 & 11.5 \\
\hline Dry matter (g/kg) & 873.0 & 862.3 & 861.2 & 862.4 & 855.2 \\
\hline Crude protein $(\mathrm{g} / \mathrm{kg})$ & 132.5 & 134.2 & 128.0 & 123.4 & 116.9 \\
\hline Lysine (g/kg) & 0.77 & 0.86 & 0.88 & 0.88 & 0.79 \\
\hline Methionine (g/kg) & 0.12 & 0.14 & 0.14 & 0.13 & 0.20 \\
\hline Threonine (g/kg) & 0.45 & 0.49 & 0.50 & 0.45 & 0.46 \\
\hline Arginine $(\mathrm{g} / \mathrm{kg})$ & 0.90 & 0.98 & 0.92 & 0.90 & 0.76 \\
\hline Ash (g/kg) & 95.0 & 98.6 & 102.3 & 106.0 & 120.6 \\
\hline Fat/ether extract $(\mathrm{g} / \mathrm{kg})$ & 25.88 & 39.13 & 64.18 & 85.98 & 95.30 \\
\hline Crude fibre (g/kg) & 126.2 & 124.7 & 123.8 & 143.8 & 136.1 \\
\hline Acid detergent fibre (g/kg) & 152.6 & 156.0 & 154.2 & 180.0 & 168.4 \\
\hline Neutral detergent fibre (g/kg) & 225.5 & 232.5 & 231.7 & 258.0 & 249.9 \\
\hline Calcium (g/kg) & 29.30 & 21.70 & 22.70 & 21.90 & 21.45 \\
\hline Phosphorous (g/kg) & 8.35 & 7.90 & 9.37 & 7.10 & 9.10 \\
\hline
\end{tabular}

${ }^{1}$ Monocalcium phosphate

${ }^{2}$ Sodium chloride

${ }^{3}$ Metabolizable energy content for ostriches (as formulated)

FFCS: full-fat canola seed

\section{Results}

The trial diets in which FFCS replaced soybean oil cake were formulated to have the same level of ME (Table 2), because ME primarily influences intake in ostriches (Brand et al., 2018). To keep these diets balanced, oat hulls were included with FFCS to compensate for its high fat content. The diets with high levels of FFCS and oat hulls have higher concentrations of EE and CF. Carstens (2013) showed that there are no differences in feed intake in birds between $11 \%$ and 14\%, although differences in growth were observed. 
The colours of the diets differed slightly (Table 4). Light reflectance $\left(L^{*}\right)$ differed $(P \leq 0.05)$ among diet. The 0\%FFCS, 50\%FFCS and 75\%FFCS had a lighter colour (although they did not differ from each other) than $25 \% \mathrm{FFCS}$ and $100 \% \mathrm{FFCS}$, except for 50\%FFCS, which did not differ $(P>0.05)$ from the $100 \% \mathrm{FFCS}$. Nor did the $25 \%$ FFCS and $100 \%$ FFCS differ from each other. There were no significant differences among the diets for $a^{\star}$ whilst the $b^{\star}$ for the $100 \%$ FFCS was lower than all the rest, which did not differ from each other.

Table 3 Glucosinolate content of full-fat canola seed and diets in which soybean oilcake meal was gradually replaced by full-fat canola seed to determine the effect on the feed preference of grower ostriches

\begin{tabular}{lcccccc}
\hline \multirow{2}{*}{ Glucosinolates ( $\boldsymbol{\mu}$ mol/g) } & Full-fat canola seed & \multicolumn{5}{c}{$\begin{array}{c}\text { Diets expressed as the percentage full-fat canola seed } \\
\text { replacing soybean oilcake meal }\end{array}$} \\
\cline { 3 - 7 } & & 0\%FFCS & 25\%FFCS & $\mathbf{5 0 \% F F C S ~}$ & $\mathbf{7 5 \% F F C S}$ & $\mathbf{1 0 0 \% F F C S}$ \\
\hline \multirow{2}{*}{ Progoitrin } & 0.947 & 0.00 & 0.065 & 0.131 & 0.195 & 0.260 \\
Sinigrin & 0.035 & 0.00 & 0.002 & 0.005 & 0.007 & 0.010 \\
Glucobrassicin & 0.186 & 0.00 & 0.013 & 0.026 & 0.038 & 0.051 \\
Gluconapin & 1.072 & 0.00 & 0.074 & 0.148 & 0.221 & 0.295 \\
4-hydroxyglucobrassicin & 2.141 & 0.00 & 0.148 & 0.295 & 0.441 & 0.589 \\
Epiprogoitrin & 2.065 & 0.00 & 0.142 & 0.285 & 0.425 & 0.568 \\
Gluconapoleiferin & 0.089 & 0.00 & 0.006 & 0.012 & 0.018 & 0.024 \\
Glucobrassicanapin & 0.209 & 0.00 & 0.014 & 0.029 & 0.043 & 0.057 \\
Gluconasturtin & 0.145 & 0.00 & 0.010 & 0.020 & 0.030 & 0.040 \\
\hline Total & 6.889 & 0.00 & 0.475 & 0.951 & 1.419 & 1.894 \\
\hline
\end{tabular}

FFCS: full-fat canola seed

Table 4 Colour attribute differences between diets, in which soybean oilcake meal was gradually replaced by full-fat canola seed

\begin{tabular}{lccccc}
\hline \multirow{2}{*}{ Surface colour attributes } & \multicolumn{5}{c}{ Diets expressed as the percentage full-fat canola seed replacing soybean oilcake } \\
meal
\end{tabular}

${ }^{\mathrm{a}, \mathrm{b}, \mathrm{c}}$ Row means with different superscripts differ significantly $(P \leq 0.05)$

FFCS: full-fat canola seed

Least square means are accompanied by the standard error of the mean

In feed intake, no differences $(P>0.05)$ were found for $\mathrm{DMl} / \mathrm{bird} /$ day or $\% \mathrm{DMl} / \mathrm{bird} / \mathrm{day}$ between camps. However, differences $(P \leq 0.05)$ were observed between diets for $\mathrm{DMl} / \mathrm{bird} /$ day and \%DMl/bird/day (Table 5). The 25\%FFCS had the highest $(P \leq 0.05) \mathrm{DMl} / \mathrm{bird} /$ day $(577.61 \pm 81.98 \mathrm{~g} / \mathrm{bird} /$ day $)(41.5 \%$ higher than $0 \% \mathrm{FFCS})$ and \%DMI/bird/day (20.5 $\pm 2.9 \% /$ bird/day) $(43.7 \%$ higher than $0 \% \mathrm{FFCS})$ compared with all the other diets. There were no differences $(P>0.05)$ in feed intake among the other diets. 
Table 5 Effect of soybean oilcake meal replacement with full-fat canola seed on the mean dry matter intake and percentage dry matter intake of five ostrich grower diets

\begin{tabular}{cccccc}
\hline & Diet & $\begin{array}{c}\text { FFCS inclusion } \\
\text { level (\%) }\end{array}$ & $\begin{array}{c}\text { Soybean replacement } \\
\text { level (\%) }\end{array}$ & $\begin{array}{c}\text { Mean DMI/Bird/Day } \\
\mathbf{( g )}\end{array}$ & $\begin{array}{c}\text { Percentage } \\
\text { DMI/Bird/Day (g) }\end{array}$ \\
\hline \multirow{4}{*}{ Treatment } & & 0 & $577.6^{\mathrm{b}} \pm 81.98$ & $20.6^{\mathrm{b}} \pm 2.95$ \\
& 1 & 0 & 25 & $817.4^{\mathrm{a}} \pm 81.98$ & $29.5^{\mathrm{a}} \pm 2.95$ \\
& 2 & 6.9 & 50 & $414.4^{\mathrm{b}} \pm 81.98$ & $14.9^{\mathrm{b}} \pm 2.95$ \\
& 3 & 13.8 & 75 & $493.2^{\mathrm{b}} \pm 81.98$ & $18.0^{\mathrm{b}} \pm 2.95$ \\
& 4 & 20.6 & 100 & $470.0^{\mathrm{b}} \pm 81.98$ & $17.0^{\mathrm{b}} \pm 2.95$ \\
\hline
\end{tabular}

a,b Column means with different superscripts differ significantly $(P \leq 0.05)$

FFCS: full-fat canola seed

Least square means are accompanied by the standard error of the mean

\section{Discussion}

Most animals consume feed primarily to satisfy their nutritional requirements (Rose \& Kyriazakis, 1991; Forbes \& Shariatmadari, 1994), thus the DMI of a poultry ration is determined first by the energy contents of the feed. Ostriches that receive feed with higher energy levels have a lower feed intake than those that receive lower energy diets (Brand et al., 2000a; Brand et al., 2000b; Brand et al., 2002; Brand et al., 2006). Because the diets in this investigation were formulated to be iso-nutritional (Table 2), the preference for 25\%FFCS (Table 5) could not be due to differences in energy content. Several other factors such as feed taste and colour or the presence of anti-nutrients may, however, also play a role in feed intake of ostriches (Kruger, 2006).

Hill (1979) reported that poultry have poorly developed senses of smell and vision, which renders taste, smell and colour of less importance in diet selection. However, Fischer et al. (1975) found that the colour pecking preferences of White Leghorn chicks were towards blue-violet and orange-red when placed in dark surroundings with various illuminated colours. When the chicks were placed in light surroundings, they had preferences for violet and yellow-orange. In both dark and light conditions, the animals discriminated against green, which received the lowest peck count. Green is a prominent background and habitat colour where most animals feed, which led Fischer et al. (1975) to postulate that the preference pecking at violet and yellow-orange might be due to the strong contrast these colours have with green and not for the colours themselves. This was explained similarly by Hailman (1968). However, the findings of Khosravinia (2007) contradict those of Fischer et al. (1975) and Hailman (1968), as they ascertained that overall, chickens prefer green to orange, red, white and yellow feed. These findings were in accord with those of Cooper (1971), who found that five out of seven pens of turkey poults consumed more green coloured feed than yellow, red, blue and natural coloured. Khosravinia (2007), however, found that significantly more of the orange feed was consumed at low light intensity.

According to Bubier et al. (1996), ostrich chicks prefer green to yellow, blue, black and red. In their study they placed ostrich chicks in a basket and presented them with five colours in the form of strips of insulation tape. The pecks were counted over $30 \mathrm{~min}$ and the frequency of pecks at a colour was calculated. Green was pecked at most, although green and white had no significant difference in pecking frequency. Bubier et al. (1996) stated that chicks were more prone to investigate feeding trays and consume pellets when a thin layer of feed created a contrast between feed and tray colour. This validates the assumption of Fischer et al. (1975). Janse van Vuuren et al. (2007) performed similar trials in which they placed various coloured flags with ostrich chicks and found that the most pecks were at the green flag. Some studies however, concluded that ostrich chicks had no definite preference for certain green coloured feed (Janse van Vuuren et al., 2007; Kruger et al., 2008).

From the results of the present trial, it was clear that the $L^{*}$ values for $50 \%$ FFCS and $25 \%$ FFCS (Table 4) were higher than for the rest of the diets, indicating that these rations were slightly whiter in colour. In $b^{*}$ values, $100 \%$ FFCS had a lower value than all the other diets and it was expected that it would have a slightly bluer appearance. Despite the differences in these two attributes, one cannot see them with the naked eye. Also the differences were too small to contribute to feed preference, since $25 \%$ FFCS had the highest DMI, but did not differ from $100 \%$ FFCS for $\mathrm{L}^{*}$, differing from $100 \%$ FFCS only for $\mathrm{b}^{*}$. Based on the findings of other studies it is not clear whether ostriches have a feed colour preference, although they do have a peck preference for green. It is more likely that a contrast in colours attracts attention and leads to higher feed 
consumption, and not a specific feed colour. Although feed colour did not have an influence on DMI in the current study, it would be of value and interest to investigate to what extent feed colour might have an effect on DMI. Factors such as feed flavour could also be influential in diet selection and warrant attention.

Sizemore \& Lillie (1956) and Romoser et al. (1958) found that flavour had no effect on intake or on feeding efficiency of chickens. Kare \& Pick (1960) suggested that because poultry have restricted saliva production, the animals have limited ability to taste and that DMI is stable, even if taste is altered. In addition, they stated that the taste of feed needs to be altered to a great extent before it influences feed intake. In contradiction, Kare et al. (1957) stated that fowls have acute ability to taste. Brand et al. (2008) found that ostriches did not have taste buds in their beaks. However, in a study of the oropharyngeal opening several delicate papillae were found on a dark semi-circular part of the posterior third part of the hard palate that may function as taste sensors (Tadjalli et al., 2008). These findings make it likely that ostriches have the ability to taste to some extent. There is also the possibility that the taste buds are lower down in the throat of the bird.

In this trial, the ostriches favoured 25\%FFCS over the control, which was the standard commercial diet that they received before the trial began. Kare \& Pick (1960) stated that poultry frequently avoid unaccustomed feed and prefer the feed to which they are used. However, the influence of FFCS on feed intake is not clear. Talebali \& Farzinpour (2005) observed that chickens in a group that received a high (12\%) FFCS inclusion diet had a higher feed intake (4016 g/bird) over a 42-day period than a group that received the control diet with no FFCS (3583 g/bird). In contract, Roth-Maier et al. (1988) found that an increase of FFCS in the diet of chickens reduced the performance of the birds. Summers et al. (1988) stated that although a precise cause for the decrease in feed intake has not been found, the lowering of feed intake may be because of the presence of phytic acid in FFCS. Phytic acid reduces the ability to absorb calcium and thus reduces feed intake. However, the results from the current study do not agree with any of these studies and statements. Only $25 \%$ FFCS was favoured over the rest of the diets, which did not differ in DMI $(P$ $>0.05$ ). There were no trends of increased or decreased DMI as FFCS inclusion increased, which rules out phytic acid as an influence because 100\%FFCS had a much higher FFCS inclusion (27.5\%) and thus a higher phytic acid concentration than the 0\%FFCS, with no difference in DMI between the two diets.

Canola contains glucosinolates (Paul et al., 1986) and a-linolenic acid (Galliard, 1980). Although canola is a variety of rapeseed that contains low levels of these compounds (DeBonte et al., 2001), they may affect the taste of the feed and influence DMI. Fenwick et al. (1983a) and Fenwick et al. (1983b) found that glucosinolates and other naturally produced pesticides and toxins taste bitter, sour and caustic. Similarly, Van Doorn et al. (1998) and Mithen et al. (2000) noted that glucosinolate metabolites in food cause a bitter taste. Hill (1991) reported that glucosinolates lead to reduced DMI in ruminants. Fenwick et al. (1983a) supported this and added that glucosinolates, namely sinigrin and progoitrin, in the feed cause bitterness and thus reduce DMI. Quinsac et al. (1994) conducted nutritional trials using rapeseed meal (Brassica napus L.) as a basis to determine to what extent glucosinolates affects the production of chickens. In their trial, the diet, which contained $300 \mathrm{~g} / \mathrm{kg}$ of rapeseed meal included $9.2 \mu \mathrm{mol} / \mathrm{g}$ of progoitrin, but had no effect on DMI. The same result was found for the diet containing $9.5 \mu \mathrm{mol} / \mathrm{g}$ of progoitrin. Full-fat canola seed has been tested in various studies to establish the concentrations of glucosinolates that affect animal performance. Quinsac et al. (1994) fed diets to broilers containing a total glucosinolate content of $15.8 \mu \mathrm{mol} / \mathrm{g}$, with no difference in feed intake compared with diets that did not contain glucosinolates. These and other studies showed that glucosinolate contents need to be much higher that the values shown in Table 3 to affect animal performance (Roth-Maier et al., 2004; Opalka et al., 2001). Other anti-nutritional factors may influence animal feed intake. $\alpha$-Linolenic acid is an unstable fatty acid that can oxidize rapidly (Galliard, 1980), and develop unpleasant aromas and a rancid taste during storage (Hawrysh, 1990). Erucic acid is another antinutrient in rapeseed that can have a toxic effect on animals if excessive amounts are consumed (Dingyuan \& Jianjun, 2007). However, low levels of erucic acid are found in canola ( $<2 \%$ of total fatty content of a seed) (DeBonte et al., 2001). Ferguson et al. (2002) found that pigs can detect toxins and anti-nutrients in feed, and would avoid intake of feed containing these harmful components. These findings about the unpleasant tastes and toxins of canola do not explain the results obtained from the present trial. The ostriches consumed more of $25 \%$ FFCS than the rest of the diets, but did not discriminate against $100 \%$ FFCS compared with 0\%FFCS. According to these studies, this should have been the case if the canola contained high levels of anti-nutrients. This might justify the assumption that these anti-nutrient levels are too low (Table 3) to influence DMI, since canola was developed to have lower levels of these compounds that influence taste (Stefansson \& Kondra, 1975; Lee et al., 1991; DeBonte et al., 2001). Based on the results of other research, Talebali \& Farzinpour (2005) concluded that feed intake inhibition does not result from the undesirable taste that canola might have.

In a study to improve the DMI of newly hatched ostrich chicks, feed flavour was altered by adding artificial flavourings (Kruger et al., 2008). Salty, sweet, bitter and sour flavours were added to a standard feed and placed in four feeding troughs. The chicks showed a preference for the salty taste. Janse van Vuuren 
(2008) ran a similar trial in which seafood, meat, citrus, mint, lucerne and aniseed flavours were provided to ostrich chicks in a free choice feeding system. The chicks tended to favour the seafood flavour in two consecutive trials. These findings support the idea that ostriches can distinguish among flavours and have preferences for salty and seafood flavours. However, Brand et al. (2018) investigated feed preferences of ostriches towards sweet and bitter lupins and a combination of the two, which replaced soybean oilcake meal in ostrich grower diets. There was no preference $(P>0.05)$ between inclusion levels. It was found only that there was a tendency $(P=0.11)$ for birds to prefer the $7.5 \%$ bitter lupin inclusion and discriminate to some extent against the $15 \%$ and $30 \%$ inclusion levels. Because of the large difference in the alkaloid content of sweet and bitter lupins to which the birds had access in the trial and because there were no differences in DMI between the two (Brand et al., 2018), this leads to the speculation that ostriches have limited ability to taste. Based on the trials conducted by Brand et al. (2018), including the current one, it was assumed that feed taste stimulates a reduced DMI response and diet flavour and aroma need to be altered to a greater extent to induce reduced DMI.

\section{Conclusion}

Diets with up to $27.5 \%$ FFCS inclusion rates had no detrimental effects on feed preference of finishing ostriches. In the diets, which was iso-nutritious in metabolizable energy and amino acid content, birds preferred $6.9 \%$ FFCS inclusion rates. The 100\% FFCS diet contained approximately $21 \%$ oat hulls, which were necessary to balance the diets in terms of energy and amino acid content. This should be kept in mind when interpreting the results. The differences between diets in fractions were small. There was no indication that the presence of anti-nutritional factors in FFCS affected the feed preference of the birds. Similarly, feed colour did not explain the higher DMI of birds on the 25\%FFCS diet. The 67\% higher feed intake and preference are difficult to explain, but for some reason the birds favoured the combination and ratio of other raw materials and FFCS in the 25\%FFCS diet. Growth trials need to be conducted to ensure birds are not influenced negatively by FFCS inclusion in their diets.

\section{Acknowledgements}

The support and financial aid of the Western Cape Agricultural Research Trust, Oil and Protein Seeds Development Trust and Western Cape Department of Agriculture are much appreciated.

\section{Authors' Contributions}

Conception and design: TSB; data collection, analyses and drafting of paper: GJN; critical revision: TSB \& LCH; final editing and drafting: GJN; critical revision and final approval of version to be published: TSB

\section{Conflicts of Interest Declaration}

The authors certify that they have no affiliations with or involvement in any organization or entity with financial or non-financial interest in the subject matter and materials discussed in this manuscript.

\section{Reference}

Abudabos, A.M. \& Aljumaah, R., 2012. Evaluation of lysine, methionine and threonine needs of broilers after 10 days of age. J. Poult. Sci. 49, 101-105.

Aganga, A.A., Aganga, A.O. \& Omphile, U.J., 2003. Ostrich feeding and nutrition. Pakistan J. Nutr. 2, 60-67.

Ajuyah, A.O., Lee, K.H., Hardin, R.T. \& Sim, J.S., 1991. Influence of dietary full-fat seeds and oils on total lipid, cholesterol and fatty acid composition of broiler meats. Can. J. Anim. Sci. 71, 1011-1019.

ALASA, 1998. Method 6.1.1: Dry ashing. In: D. Palic (ed). Handbook of Feeds and Plant Analysis. ALASA, Hatfield, Pretoria, South Africa.

AOAC, 2012. Official Methods of Analysis. 19th edition. Association of Official Analytical Chemists, Arlington, Virginia, USA.

Bell, J.M., 1993. Factors affecting the nutritional value of canola meal: A review. Can. J. Anim. Sci. 73, 679-697.

Bradford, G.E., 1999. Contributions of animal agriculture to meeting global human food demand. Livest. Prod. Sci. 59, 95-112.

Brand, T.S. \& Jordaan, J.W., 2004. Ostrich nutrition: Cost implications and possible savings. Feed Tech. 8, 22-25.

Brand, T.S. \& Gous, R.M., 2006. Feeding Ostriches. In: V. Bels (ed). Feeding in Domestic Vertebrates: From structure to behaviour. 1st edition. CABI, Wallingford, England. pp. 136-155.

Brand, T.S., De Brabander, L., Van Schalkwyk, S.J., Pfister, B. \& Hays, J.P., 2000a. The true metabolizable energy content of canola oilcake meal and full-fat canola seed for ostriches (Struthio camelus). Br. Poult. Sci. 41, 201-203.

Brand, T.S., Van der Merwe, J.P., Salih, M. \& Brand, Z., 2000b. Comparison of estimates of feed energy obtained from ostriches with estimates obtained from pigs, poultry and ruminants. S. Afr. J. Anim. Sci. 30, 13-14.

Brand, Z., Brand, T.S. \& Brown, C.R., 2002. The effect of dietary energy and protein levels on body condition and production of breeding male ostriches. S. Afr. J. Anim. Sci. 32, 231-239.

Brand, T.S., Brandt, D.A. \& Cruywagen, C.W., 2004. Chemical composition, true metabolizable energy content and amino acid availability of grain legumes for poultry. S. Afr. J. Anim. Sci. 34, 116-122. 
Brand, T.S., Aucamp, B.B. \& Kruger, A.C.M., 2006. The effect of pelleting on the diet utilization by ostriches. Proc. 41st South African Society Animal Science Cong, Bloemfontein, South Africa. pp. 3-6.

Brand, T.S., Smith, N. \& Hoffman, L.C., 2007. Anti-nutritional factors in canola produced in the Western and Southern Cape areas of South Africa. S. Afr. J. Anim. Sci. 37, 45-50.

Brand, T.S., Kruger, A.C.M. \& Aucamp, B.B., 2008. The effect of feeding management practices on the feed intake and production performance of newly hatched ostrich chicks. Proc. Ostrich Inf. Day, Oudtshoorn, South Africa.

Brand, T.S., Engelbrecht, J.A., Van der Merwe, J. \& Hoffman, L.C., 2018. Feed preference of grower ostriches consuming diets differing in Lupinus angustifolius inclusion levels. S. Afr. J. Anim. Sci. 48, 170-185.

Brand, T.S., Viviers, S.F., Van der Merwe, J. \& Hoffman, L.C., 2018. The influence of different dietary energy concentrations on the production parameters of feedlot ostriches. S. Afr. J. Anim. Sci. 48, 162-169.

Bubier, N.E., Lambert, M.S., Deeming, D.C., Ayres, L.L. \& Sibly, R.M., 1996. Time budget and colour preferences (with specific reference to feeding) of ostrich (Struthio camelus) chicks in captivity. Br. Poult. Sci. 37, 547-551.

Busboom, J.R., Rule, D.C., Colin, D., Heald, T. \& Mazhar, A., 1991. Growth, carcass characteristics, and lipid composition of adipose tissue and muscle. J. Anim. Sci. 69, 1101-1108.

Cao, Y. \& Li, D., 2013. Impact of increased demand for animal protein products in Asian countries: Implications on global food security. Animal Frontiers 3, 48-55.

Carstens, P.D., 2013. Studies to develop a mathematical optimisation model to describe the effect of nutrition on the growth of ostriches (Struthio camelus var. domesticus). MSc (Agric) thesis, University of Stellenbosch, South Africa.

Cooper, J.B., 1971. Colored feed for turkey poults. Poult. Sci. 50, 1892-1893.

Dale, N., 1996. Variation in feed ingredient quality: Oilseed meals. Anim. Feed Sci. Technol. 59, 129-135.

DeBonte, L.R., Loh, W.H.T. \& Zhegong, F., 2001. Canola variety producing a seed with reduced glucosinolates and linolenic acid yielding an oil with low sulfur, improving sensory characteristics and increased oxidative stability. US Patent, US 6,270,828 B1.

Dingyuan, F. \& Jianjun, Z., 2007. Nutritional and anti-nutritional composition of rapeseed meal and its utilization as a feed ingredient for animal. International Consultative Group for Research on Rapeseed, Wuhan, China. pp. 265-271.

Engelbrecht, J.A., 2016. The evaluation of lupins (Lupinus angustifolius) as alternative protein source to soybean oilcake meal in ostrich (Struthio camelus var. domesticus) diets. MSc (Agric) thesis, University of Stellenbosch, South Africa.

Fenwick, G.R., Griffiths, N.M. \& Heaney, R.K., 1983a. Bitterness in brussels sprouts (Brassica oleracea L. var. gemmifera): The role of glucosinolates and their breakdown products. J. Sci. Food Agric. 34, 73-80.

Fenwick, G.R., Heaney, R.K., Mullin, W.J. \& VanEtten, C.H., 1983b. Glucosinolates and their breakdown products in food and food plants. Food Sci. Nutr. 18, 123-201.

Ferguson, N.S., Bradford, M.M.V. \& Gous, R.M., 2002. Diet selection priorities in growing pigs offered a choice of feeds. S. Afr. J. Anim. Sci. 32, 136-143.

Fischer, G.J., Morris, G.L. \& Ruhsam, J.P., 1975. Color pecking preferences in White Leghorn chicks. J. Comp. Physiol. Psychol. 88, 402-406.

Forbes, J.M. \& Shariatmadari, F., 1994. Diet selection for protein by poultry. Wrlds. Poult. Sci. J. 50, 7-24.

Galliard, T., 1980. Degradation of acyl lipids: Hydrolytic and oxidative enzymes. In: P.K. Stumpf (ed). Lipids: Structure and function: The biochemistry of plants. 4th edition. Academic Press, New York. pp. 85-116.

Gardner, B., 2013. Global Food Futures: Feeding the World in 2050. 1st edition. A \& C Black, London. pp. 140-150.

Girolami, A., Marsico, I., D'Andrea, G., Braghieri, A., Napolitano, F. \& Cifuni, G.F., 2003. Fatty acid profile, cholesterol content and tenderness of ostrich meat as influenced by age at slaughter and muscle type. Meat Sci. 64, 309-315.

Goering, H.K. \& Van Soest, P.J., 1970. Forage fiber analyses (apparatus, reagents, prcedures, and some applications). In: Agricultural Handbook No. 379. US Department of Agriculture, Washington.

Gous, R.M. \& Brand, T.S., 2008. Simulation models used for determining food intake and growth of ostriches: An overview. Aust. J. Exp. Agric. 48, 1266-1269.

Hailman, J.P., 1968. Spectral Reflectance of Gull's Bill: Physiological and evolutionary implications for animal communication. Science 162, 139-140.

Harris, S., Morris, C., Jackson, T., Lucia, L.M., Hale, D.S., Miller, R.K., Keeton, J.T., Savell, J.W. \& Acuff, G.R., 1994. Ostrich meat industry development. Final report. Texas Agricultural Extension Service, College Station, Texas, USA.

Hawrysh, Z.J., 1990. Stability of canola oil. In: F. Shahidi (ed). Canola and Rapeseed: Production, chemistry, nutrition, and processing technology. Van Nostrand Reinhold, New York, USA. pp. 99-122.

Hill, R., 1979. A Review of the toxic effects of rapeseed meal with observation on meal from improved varieties. Br. Vet. J. 135, 3-16.

Hill, R., 1991. Rapeseed meal in diets of ruminants. Nutr. Abstr. Rev. 61, 140-155.

Janse van Vuuren, M., 2008. Factors that will affect the survival of ostrich (Strathio camelus) chicks. MTech thesis, Nelson Mandela Metropolitan University, George, South Africa. (in Afrikaans)

Janse van Vuuren, M., Brand, T.S. \& Aucamp, B.B., 2007. Colour preferences in ostrich (Struthio camelus) chicks. Proc. South African Society for Animal Science. Warmbaths, South Africa.

Jordaan, J.W., Brand, T.S., Bhiya, C. \& Aucamp, B.B., 2008. An evaluation of slaughter age on the profitability of intensive slaughter ostrich production. Aust. J. Exp. Agric. 48, 916-920.

Kare, M.R., Black, R. \& Allison, E.G., 1957. The sense of taste in the fowl. Poult. Sci. 36, 129-138.

Kare, M.R. \& Pick, H.L., 1960. The influence of the sense of taste on feed and fluid consumption. Poult. Sci. 39, $697-706$. 
Khosravinia, H., 2007. Preference of broiler chicks for color of lighting and feed. J. Poult. Sci. 44, 213-219.

Kruger, A.C.M., 2006. The effect of different management practices on the feed intake and growth rate of ostrich chicks. MTech thesis, Nelson Mandela Metropolitan University, Port Elizabeth, South Africa.

Kruger, A.C M., Brand, T.S. \& Aucamp, B.B., 2008. The effect of artificially flavoured mash on the feed intake of ostrich chicks. Proc. 26th Ann. Congr. South African Soc. Agric. Technol. Langebaan, South Africa. pp. 169.

Lee, K.H., Olomu, J.M. \& Sim, J.S., 1991. Live performance, carcass yield, protein and energy retention of broiler chickens fed canola and flax full-fat seeds and the restored mixtures of meal and oil. Can. J. Anim. Sci. 71, 897-903.

Mir, Z., MacLeod, G.K., Buchanan-Smith, J.G., Grieve, D.G. \& Grovum, W.L., 1984. Methods for protecting soybean and canola proteins from degradation in the rumen. Can. J. Anim. Sci. 64, 853-865.

Mithen, R.F., Dekker, M., Verkerk, R., Rabot, S. \& Johnson, I.T., 2000. The nutritional significance, biosynthesis and bioavailability of glucosinolates in human foods. J. Sci. Food Agric. 80, 967-984.

Opalka, M., Dusza, L., Staszkiewicz, J., Lipinski, K. \& Tywonczuk, J., 2001. Effect of long-trem feeding with graded levels of low glucosinolate rapeseed meal on endocrine status of gilts and their piglets. Livest. Prod. Sci. 69, $233-243$.

Osterhoff, D.R., 1979. Ostrich Farming in South Africa. In: World Review of Animal Production XV. pp. 19-30.

Paul, N.K., Johnston, T.D. \& Eagles, C.F., 1986. Inheritance of S-methyl-L-cysteine sulphoxide and thiocyanate contents in forage rape (Brassica napus L.). Theor. Appl. Genet. 72, 706-709.

Quinsac, A., Lessire, M., Krouti, M., Ribaillier, D., Coïc, J.P., Fauduet, H., Rollin, P., 1994. Improvement in the nutritive value of high and low glucosinolate rapeseed meal by aqueous extraction. Anim. Feed Sci. Technol. 48, 265-272.

Romoser, G.L., Bossard, E.H. \& Combs, G.F., 1958. Studies on the use of certain flavors in the diet of chicks. Poult. Sci. 37, 631-633.

Rose, S.P. \& Kyriazakis, I., 1991. Diet selection of pigs and poultry. Proc. Nutr. Soc. 50, 87-98.

Roth-Maier, D.A. \& Kirchgessener, M., 1988. Feeding of 00-rapeseed to fattening chicken and laying hens. Landwirtsch Forschung. 41, 140-150 (cited by Talebali \& Farzinpour, 2005).

Roth-Maier, D.A., Böhmer, B.M. \& Roth, F.X., 2004. Effect of feeding canola meal and sweet lupin(L. luteus, L. angustifolius) in amino acid balanced diets on growth performance and carcass characteristics of growingfinishing pigs. Anim. Res. 53,21-34.

Sales, J. \& Hayes, J.P., 1996. Proximate, amino acid and mineral composition of ostrich meat. Food Chem. 56, 167-170.

Sasaki, K., Neyazaki, M., Shindo, K., Ogawa, T. \& Momse, M., 2012. Quantitative profiling of glucosinolates by LC-MS analysis reveals several cultivars of cabbage and kale as promising sources of sulforaphane. J. Chromatogr. B, 903,171-176

Sizemore, J.R. \& Lillie, R.J., 1956. Lack of effect of a synthetic poultry feed flavor on chick growth and feed efficiency. Poult. Sci. 35, 360-361.

Smit, D.J.v.Z., 1964. Ostrich farming in the the Klein Karoo. Bulletin No 35, Department of Agricultural Technical Services, Pretoria. pp. 2-12.

Sridhar, K.R. \& Bhat, R., 2007. Lotus - A potential nutraceutical source. J. Agric. Technol. 3, 143-155.

Stefansson, B.R. \& Kondra, Z.P., 1975. Tower summer rape. Can. J. Plant Sci. 55, 343-344.

Summers, J.D., Leeson, S. \& Spratt, D., 1988. Canola meal and egg size. Can. J. Anim. Sci. 68, 907-913.

Tadjalli, M., Mansouri, S.H. \& Poostpasand, A., 2008. Gross anatomy of the oropharyngeal cavity in the ostrich (Struthio camelus). Iran. J. Vet. Res. 4, 316-323.

Talebali, H. \& Farzinpour, A., 2005. Effect of different levels of full-fat canola seed as a replacement for soybean meal on the performance of broiler chickens. Int. J. Poult. Sci. 4, 982-985.

Taylor, M.J.C., 2017. Personal communication. Central Analytical Facilities, Stellenbosch University, Stellenbosch, South Africa. 4 October 2017.

Thirsk, J., 1989. The agrarian history of England and Wales. 2nd edition. Cambridge University Press, Cambridge, England. pp. 294.

Van Doorn, H.E., Van der Kruk, G.C., Van Holst, G., Raaijmakers-Ruijs, N.C.M.E., Postma, E., Groeneweg, B. \& Jongen, M.F., 1998. The glucosinolates sinigrin and progoitrin are important determinants for taste preference and bitterness of Brussels sprouts. J. Sci. Food Agric. 78, 30-38.

Van Soest, P.J., Robertson, J.B. \& Lewis, B.A., 1991. Methods for dietary fiber, neutral detergent fiber, and nonstarch polysaccharides in relation to animal nutrition. J. Dairy Sci. 74, 3583-3597.

Van Zyl, P.L., 2001. An economic evaluation of ostrich farming in the Oudtshoorn district. MSc (Agric) thesis, Stellenbosch University, South Africa. 